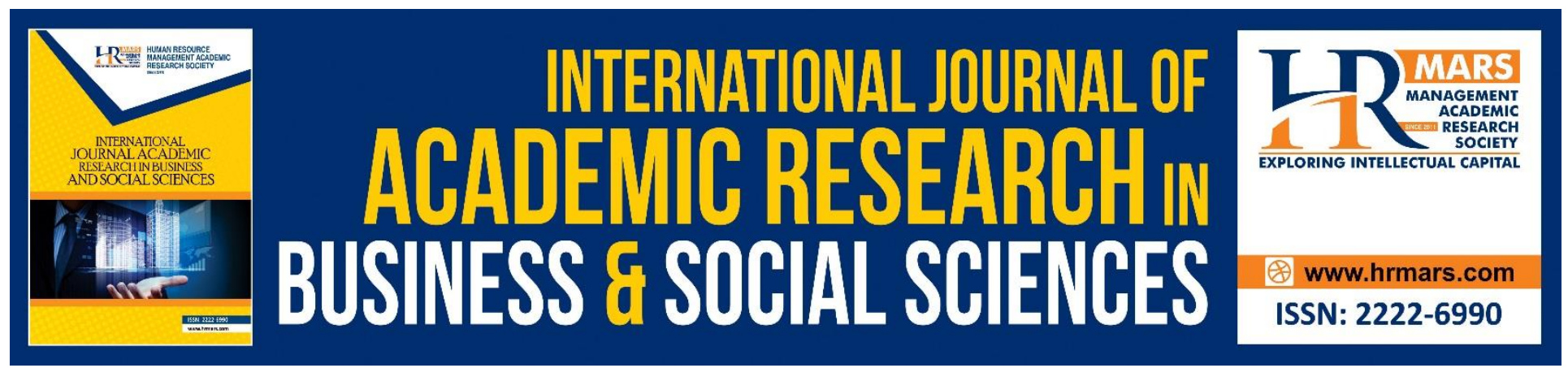

\title{
Study on Job Satisfaction among Teachers in Sultanate of Oman
}

Najeeb Al Qalhati, Asif Mahbub Karim, Bader Al Mughairi, Khalid Al Hilali, Mohammad Imtiaz Hossain

To Link this Article: http://dx.doi.org/10.6007/IJARBSS/v10-i10/7951 DOI:10.6007/IJARBSS/v10-i10/7951

Received: 20 August 2020, Revised: 19 September 2020, Accepted: 25 September 2020

Published Online: 22 October 2020

In-Text Citation: (Al Qalhati, et al., 2020)

To Cite this Article: Al Qalhati, N., Karim, A. M., Al Mughairi, B., Al Hilali, K., \& Hossain, M. I. (2020). Study on Job Satisfaction among Teachers in Sultanate of Oman. International Journal of Academic Research in Business and Social Sciences. 10(10), 422-434.

\section{Copyright: (c) 2020 The Author(s)}

Published by Human Resource Management Academic Research Society (www.hrmars.com)

This article is published under the Creative Commons Attribution (CC BY 4.0) license. Anyone may reproduce, distribute, translate and create derivative works of this article (for both commercial and non-commercial purposes), subject to full attribution to the original publication and authors. The full terms of this license may be seen at: http://creativecommons.org/licences/by/4.0/legalcode

Vol. 10, No. 10, 2020, Pg. 422 - 434

Full Terms \& Conditions of access and use can be found at http://hrmars.com/index.php/pages/detail/publication-ethics 


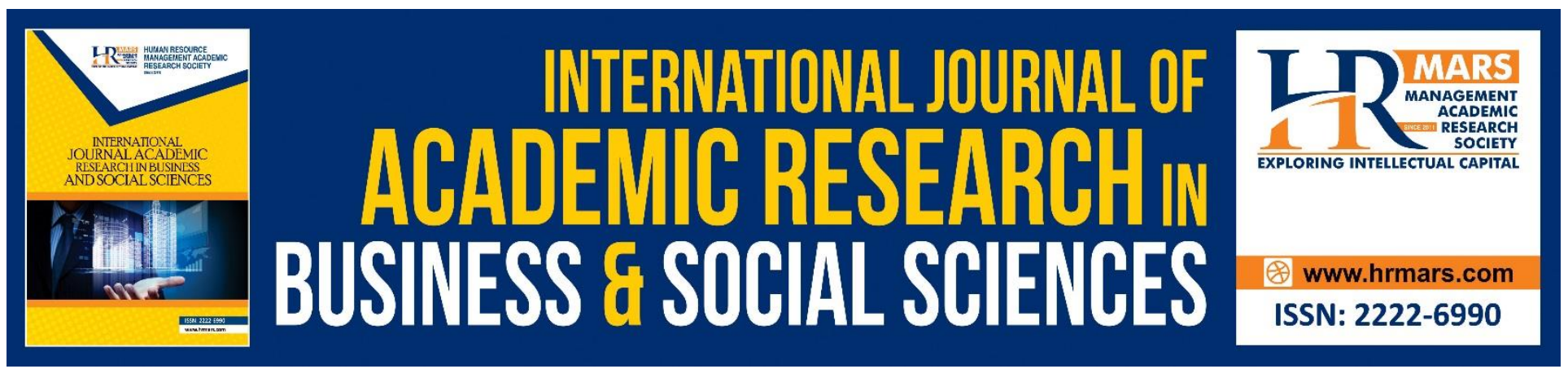

\title{
Study on Job Satisfaction among Teachers in Sultanate of Oman
}

\author{
${ }^{1}$ Najeeb Al Qalhati, ${ }^{2}$ Dr. Asif Mahbub Karim, ${ }^{3}$ Bader Al Mughairi, \\ ${ }^{4}$ Khalid Al Hilali, ${ }^{5}$ Mohammad Imtiaz Hossain \\ 1,3,4 PhD, Research Fellow, Binary University, Malaysia, ${ }^{2}$ Associate Professor and Dean, Binary \\ Graduate School, Binary University, ${ }^{5}$ Postgraduate Student, Universiti Putra Malaysia
}

\begin{abstract}
The high rate of education quality in Oman is attributed to the enhanced professional development that has brought a range of merits to both, the students and the education service providers in Oman. The efficient learning environment in Oman is a result of a teacher development that has not occurred overnight but was caused by the cumulative growth of quality teachers through a qualitative training program. While the provision of a conducive teaching and learning environment is necessary for teachers on their part, teachers have to impact the school morale by motivating the learners positively. Indeed, this type of motivation can be credited to the pre-service training that the teachers in Oman get to position their learners properly for them to be imparted with the correct knowledge, skills, beliefs, and attitudes. Moreover, teachers have to be satisfied with their work to focus on enhancing their skills and expertise. Consequently, this paper seeks to discuss job satisfaction among teachers in Oman.
\end{abstract}

Keywords: Job Satisfaction, Teachers, Motivation.

\section{Introduction}

The teaching profession is supposed to be interesting since it is a job, requiring an individual to take a deep thought and meditate before choosing it as a life career. Becoming a teacher or choosing a teaching job has been difficult for various reasons. Teachers across the globe fight hard for their voice to be heard. Matters to do with their salaries and respect from the society are mega issues. Job satisfaction is a crucial issue for this generation professionals. Provided a special focus on teachers (Javed et al., 2020) coined that teachers, confronted with huge duties and responsibilities such as workload (administrative as well as academic), stressful longer working hours and others, tend to be affected in terms of their level of job satisfaction and performance. (Hossain et al., 2018) acknowledged that above $60 \%$ of Malaysian workforce felt that they can't manage time for their families due to long working hours which could have leads them to dissatisfaction and risk of turnover. In another study (Hossain et al., 2018) noted some consequence of turnover like high financial cost and operation cost for recruiting and training new employees. Hence, students from various parts of the globe are not convinced enough about pursuing this profession. However, in 
INTERNATIONAL JOURNAL OF ACADEMIC RESEARCH IN BUSINESS AND SOCIAL SCIENCES Vol. 10, No. 10, 2020, E-ISSN: 2222-6990 @ 2020 HRMARS

Oman, the situation is different, even though it is a result of the renaissance of education that commenced after Sultan Qaboos ascended the throne. Before, Oman teachers were not exempted from the problems that other teachers across the globe experienced. Consequently, it is significant to learn from Oman's story about how they have created an efficient teaching environment that many teachers across the globe have emulated. Numerous factors have, therefore, motivated their teachers to stay in the profession, as revealed in this article.

\section{Literature Review}

Numerous factors have streamlined the positive demands of the teachers in the Sultanate of Oman. Khan and Mishra (2013) state that the factors include gender, age, experience, qualification, place of work, salary, amount of paid vacation time, and opportunities for professional development. Other significant factors that determine the rate of teacher's satisfaction in Oman include the fair reward systems, regular classroom supervision, provision of feedback, useful staff programs, and observation of the experienced teachers as they instruct students. Other factors, such as the relationship with the headmaster, peers, the supervisor, pupils, management of students' behaviors, school support for behaviors, teachers' workload, flexibility in scheduling, the location of the school, and health insurance benefits contribute to the positive demand for teachers in Oman.

Oman, as an Arab country, has a history of a male-dominated society due to the socio-religious values of the predominantly Muslim community (Al-Senaidi et al., 2009). The teaching profession has enhanced the perception of gender parity in different ways (Issan and Gomaa, 2010). From a tender age, the Oman environment orients girls to teaching as the sole suitable work option, and this is where their ambitions are first invested. Most of the fields are predominantly occupied by the men, but teaching is the only liberal option where the girls are oriented. The socialization aspect is powerful enough to ensure that the conservative society empowers women.

The satisfaction levels of teachers are further motivated by immediate employability and good working terms that are highly attractive to teaching. Currently, Issan and Gomaa (2010) state that once sexually segregated society of Oman is experiencing a situation where men reveal increasing their desire to marry working women. Their best option is to marry a teacher since their education system balances the equation of getting the extra family income and keeping with the family tradition simultaneously. Oman has put in place measures to promote gender balance in the teaching profession. One of the interventions is teaching both, boys and girls in the same classroom. The girls' schools are entirely staffed by female teachers, which explains the high rates of women in the teaching staff of the country (Issan and Gomaa, 2010; Mohamed Emam, 2016). Oman has a high retention rate of female faculty just as their male counterparts. The results of this positive impact mean that they can handle their role and deal with overloads. Likewise, the teachers can cope on measures of personal strains. Female teachers are, therefore, better placed at a career which aids them in balancing their daily workloads, which range from their school obligations to their domestic commitments. Consequently, women within the teaching profession in Oman are motivated to pursue their profession. The job satisfaction among teachers in Oman is guaranteed by the gratification of higher needs, including income, work holidays, and allowances among others (Amzat and Al-Neimi, 2014). Most significantly, age is one of these factors. The level of education is not a determining factor in teacher's job satisfaction since teachers with long experience are inclined towards better job satisfaction. Age and experience contribute to the efficiency of service delivery among teachers in Oman (Amzat and Al-Neimi, 2014). Just like wine, the longer they stay in their job, 
INTERNATIONAL JOURNAL OF ACADEMIC RESEARCH IN BUSINESS AND SOCIAL SCIENCES Vol. 10, No. 10, 2020, E-ISSN: 2222-6990 @ 2020 HRMARS

the finer they become. The ratification of the teacher's needs is also realized as they age. The teachers' pay often rises as they age. There is the implication that the teachers in Oman earn better wages and count much of their achievement as they mature within the profession.

Initially, the Teachers Institutes were the sole organizations that trained teachers in Oman. In the 1970s, they were elevated into Colleges of Education and later integrated into large university systems that eventually offered a bachelor's degree (Nasser, 2019). Under the leadership of Sultan Qaboos, Directory General for Evaluation and Development was established as a part of the higher education development (Issan and Gomaa, 2010). Sultan Qaboos University was founded in 1986 with five constituent colleges, including Education, Sciences, Agriculture, Medicine, Humanities, and Engineering. Additionally, numerous educational establishments have been made for educational teacher training (Issan et al., 2011). Education systems practices that Oman teachers have adopted are equivalent to those in Malaysia, United States of America, United Kingdom, Canada, and Australia (Issan, and Gomaa, 2010). The teachers only have to take into account the Oman values and traditions as they position their students to be at par with the global context.

The cultural background of Oman society suggests the environment where teachers are expected to have high job satisfaction. Ambusaidi and Al-Shuaili (2009) state that government policies and legislation promote the fact that teachers should have proper pay due to their administrative duties and financial obligations. One factor that is pivotal to this aspect is teacher qualification. The Sultanate of Oman has a long-standing human resource policy development that is attained through education and training. The Oman government has made steady strides to improve education quality, even though its higher education system is relatively in its young stage (Ambusaidi and Al-Shuaili, 2009). In Oman, there is an efficient, professional preparation that takes place in several stages. In the beginning, the first qualification of the teachers is General Diploma which is meant for secondary school teachers at the expense of the Ministry of Social Affairs, and from here, they can proceed to obtain their Diploma degrees. The training empowers the teachers with the necessary skills that can aid them in handling the tasks that are related to the job. The training also enables them to gauge the economic profits, premiums, salaries, and rewards that come as a result of their career. The competency dimension of their job also indicates that the teachers are contented with their job whichever place they are working, ranging from Muscat, the capital city to the rural of interior sultanates.

The nature of the teacher's job in Oman, their workplace environment, their employee-friendly organizational culture, and policies have a positive impact on their service delivery (Alyahmadi, 2012). Teachers are satisfied with their well-being. Hence, they have little intentions of quitting their duties. The government of Oman has provided resources that teachers require. Moreover, Issan et al. (2011) state that instructors have the feeling that their employer is supportive since it has helped integrate their work and family-related issues. Consequently, they exhibit higher levels of job satisfaction and organizational commitment. Teachers in Oman are determined to pursue their career.

Oman school principals were once powerless purveyors of Central Ministry policies and plans that they used to enact entirely (Wiseman, 2009). The negative aspect of this type of leadership was often detrimental to teacher development. Currently, their role identity has transformed, and this new mindset seems to be a significant step in the growth of their profession. Principals in Oman have undergone a paradigm to meet the twenty-first century needs. The transition has changed from the typical hierarchy and maintenance to collegiality, change, teamwork, effectiveness, and continuous improvement. The principals are skillful in their implementation of school-based decision making, 
INTERNATIONAL JOURNAL OF ACADEMIC RESEARCH IN BUSINESS AND SOCIAL SCIENCES Vol. 10, No. 10, 2020, E-ISSN: 2222-6990 @ 2020 HRMARS

and this has positively enhanced their leadership behavior (Westrick and Miske, 2009). The primary beneficiaries of this shift are the learners. Moreover, the identity shift has swept through to the teachers, where it is one of the motivating factors. With an efficient servant leadership system, as supported by Cerit (2010), the teachers have developed a more effective approach of reaching the curriculum goals and following education programs of the Sultanate of Oman schools (Al-Mahdy et al., 2016). Notably, servant leadership has enhanced teacher satisfaction in the Omani cultural context.

In Oman, schools have the autonomy to administer their training programs, and this includes the development of curriculum and collaborative initiatives that surround the development of the capacity of their local teacher trainees through training programs (Al-Issa, 2008). All these, according to Ghavifekr and Ibrahim (2014), are systematic with the national and strategic initiatives. As a selfsufficiency initiative, it is a general aim that seeks to sustain Omani teachers and develop efficient teacher training programs. One consequence of this initiative is that it has encouraged the teachers to facilitate the collaboration of the communities into the school programs.

Consequently, the Ministry of Education conducts the assessment of school supervisors and school teachers. The assessment takes an all-around approach whereby it covers all the aspects of the school system through great concurrent strides (Al Barwani et al., 2012). Teachers obtain intrinsic and extrinsic motivation since they are assured that they have a caring government, well represented by the supervisors (Emam, 2016). It is this measure from their supervisors that encourages them to cover all the aspects of the school system by providing continuous professional development, necessary for classroom practices and quality improvement (Al-Malki, 2014). The sharing of teacher's expertise with the non-teaching staff and the community is a collaborative effort that arises from a good relationship between the teachers and their supervisors (Nasser, 2019). The relationship between the teachers, their supervisors, and the government initiates the recognition and promotion of teachers, especially among the teachers who demonstrate good results. In megacities, like Muscat and Al-Dakhelya, the teachers are often encouraged to display and forward their ideas and efforts through their school administrators. These reports are, therefore, used for promotion and motivation.

Before the renaissance of education in Oman, teacher turnover was one of the widespread and critical educational problems that was experienced in Oman. Early retirement among the disenchanted experienced teachers was common since the teachers often turned to other occupations to boost their income. All these were the foundation of the educational problems that were experienced in the Sultanate of Oman. To substitute the unmotivated work environment, the Sultanate of Oman made a veritable emphasis on the financial factors. Presently, Omam has a few hundreds of private and public schools (Alyahmadi and Al-Kiyumi, 2014). The standard quality of school's ranges from small preschools with approximately 50 pupils with two to three teachers and assistants to the large international certified schools with over thousands of students and hundreds of faculty deans and administrators (Alyahmadi and Al-Kiyumi, 2014). The quality of education goes hand in hand with the cost associated. Prominent schools employ the best pool of talented teachers who adhere to quality standards. Gonzalez et al. (2008) state that Oman has a range of competitive teachers throughout the globe due to their suitable perks that act as the magnet, attracting worldclass professionals.

The high demand of global teachers who apply for teaching vacancies in Oman alone is an indicator that the teachers in Oman are heftily paid (Alyahmadi and Al-Kiyumi, 2014). Alyahmadi and Al-Kiyumi 
INTERNATIONAL JOURNAL OF ACADEMIC RESEARCH IN BUSINESS AND SOCIAL SCIENCES Vol. 10, No. 10, 2020, E-ISSN: 2222-6990 @ 2020 HRMARS

(2014) state that the general monthly salaries of Oman are not constant, and they range from between RO400 to 2,400. The teachers are additionally entitled to medical insurance, accommodation, and flight tickets. The significant merits for the large and kindergarten schools include a tax-free salary, annual flights, accommodation, medical and health insurance, and gratuity or end of service bonus that is given to the teachers in Oman (Al-Said and Emam, 2014). Consequently, even the smaller institutions provide for the merits, mentioned as mandated by the labor laws of Oman.

The positive bond between instructors and students is one of the altruistic reasons why teachers in Oman are committed to their relationship with the students, peers, career planners, and supervisors (Al Jardani, 2012). The love here has gifted the teachers in Oman with the autonomy and professional freedom that ensure they are satisfied with their job. As noted earlier, the teaching environment in Oman has a positive influence on the teacher's morale and sense of community.

\section{Problem Statement}

The Sultanate of Oman, like any other states, has their demographics that depict the increasing levels of stress among workers, characterized by insecurities and competitions in life. Teachers are not exempted, and they have to work hard to balance issues that have become extremely significant in life. Teachers in Oman also look for ways to help them in balancing between their work and personal life effectively. In the Sultanate of Oman, human services are pivotal for their realization of the 'Vision 2020 for Oman's National Economy' that was laid by his highness Sultan Qaboos ruler of Oman. Hence, teachers are the pillar of the development that Oman requires. Thus, their well-being is significant. All these factors make the study of work-life balance of the teachers in Oman necessary as far as the education sector and the economy of Oman are concerned.

\section{Research Question}

Job satisfaction among teachers in Oman enhances the level of performance. So, what are the motivating aspects that determine the level of job satisfaction among these teachers?

\section{Methodology}

Both, qualitative and quantitative research methods were used to conduct the research. The roles, played by these types of research were expansive. The data from qualitative research was instrumental towards finding the demographics of the teachers in Oman and the critical information, including the data that was collected on the previous studies before this study (Bryman, 2017). In the end, it helped in the formation of valuable data that was used to arrive at the factors that motivate teachers in Oman. Moreover, a combination of qualitative and quantitative research methods aided in the development of the content about the various factors that enhance teacher motivation in Oman. All the significant facts about the research data, including the variances in the level of job satisfaction among Omani teachers were obtained through a quantitative research method. Bryman (2017) states that the benefit of combining the two research methods is that they ensure that a clear statistical analysis is provided to avoid marginal era within the research study.

This research study was sociological and economic-based research that used snowballing or chain sampling (Sadler et al., 2010). The research had to recruit subjects (teachers) who were acquainted with the teaching environment and the motivational factors that enhanced their motivation while 
INTERNATIONAL JOURNAL OF ACADEMIC RESEARCH IN BUSINESS AND SOCIAL SCIENCES Vol. 10, No. 10, 2020, E-ISSN: 2222-6990 @ 2020 HRMARS

conducting their practice in Oman. As a researcher, I was specific to the teacher's population, and my primary focus was on the factors that motivated them at work.

Notably, this study used questionnaires as a tool for data gathering. The preparation and organization were essential. After setting the objectives and preparing the required information in a semistructured interview manner, as stated by Adejimi and Ogunsanmi (2010), they were administered to the relevant parties. The open-ended questions enabled the subjects to be elaborative over the inquiries that were made.

\section{Findings}

The survey was conducted with one thousand respondents who comprised the individuals of the primary research paper. The paper gauged them on the level of job satisfaction based on certain reservations and considerable environment that the teacher in Oman experiences. The results which were exclusive on teachers are demonstrated in Tab.1

Tab.1 The Results.

\begin{tabular}{|c|c|c|c|c|c|}
\hline Question & $\begin{array}{l}\text { Respondent } \\
\mathrm{S}\end{array}$ & $\begin{array}{l}\text { Non } \\
\text { Participant } \\
\text { s }\end{array}$ & Response & $\begin{array}{l}\text { Percentage } \\
\%\end{array}$ & Reflection \\
\hline Gender & 977 & 29 & $\begin{array}{l}\text { Genders } \\
\text { Males } \\
\text { Females }\end{array}$ & $\begin{array}{l}27 \% \\
73 \%\end{array}$ & $\begin{array}{l}\text { Most of the } \\
\text { teachers in } \\
\text { Oman are } \\
\text { female } \\
\text { teachers }\end{array}$ \\
\hline Age & 987 & 14 & $\begin{array}{l}\text { Years } \\
22-25 \\
26-30 \\
31-35 \\
36-40 \\
41-45 \\
46-50 \\
56+\end{array}$ & $\begin{array}{l}3.24 \% \\
29.69 \% \\
39.01 \% \\
20.47 \% \\
6.69 \% \\
4 \% \\
0.51 \%\end{array}$ & $\begin{array}{l}\text { Teachers } \\
\text { from these } \\
\text { age groups } \\
\text { are more into } \\
\text { teaching } \\
\text { because at } \\
\text { these ages, } \\
\text { they have } \\
\text { enriched } \\
\text { knowledge } \\
\text { combined } \\
\text { with proper } \\
\text { education to } \\
\text { enable them } \\
\text { empower } \\
\text { people. }\end{array}$ \\
\hline Experience & 990 & 11 & $\begin{array}{l}\text { Period } \\
1-5 \\
6-10 \\
11-15 \\
16-20\end{array}$ & $\begin{array}{l}25.15 \% \\
30.20 \% \\
28.08 \% \\
10.81 \%\end{array}$ & $\begin{array}{l}\text { Most } \\
\text { teachers have } \\
6 \text { to } 10 \text { years' } \\
\text { experience }\end{array}$ \\
\hline
\end{tabular}


INTERNATIONAL JOURNAL OF ACADEMIC RESEARCH IN BUSINESS AND SOCIAL SCIENCES Vol. 10, No. 10, 2020, E-ISSN: 2222-6990 @ 2020 HRMARS

\begin{tabular}{|c|c|c|c|c|c|}
\hline & & & $\begin{array}{l}21-25 \\
26-30 \\
31-35 \\
36+ \\
\end{array}$ & $\begin{array}{l}4.85 \% \\
0.81 \% \\
0.10 \% \\
0 \% \\
\end{array}$ & \\
\hline $\begin{array}{l}\text { Teaching } \\
\text { level }\end{array}$ & 950 & 51 & $\begin{array}{l}\text { Level } \\
\text { Primary } \\
\text { Preparatory } \\
\text { Secondary }\end{array}$ & $\begin{array}{l}27.37 \% \\
22.21 \% \\
50.42 \%\end{array}$ & $\begin{array}{l}\text { Most } \\
\text { teachers in } \\
\text { Oman are } \\
\text { engaged in } \\
\text { the secondary } \\
\text { level } \\
\text { education } \\
\text { system }\end{array}$ \\
\hline Qualification & 990 & 11 & $\begin{array}{l}\text { Education } \\
\text { Diploma } \\
\text { Bachelor } \\
\text { Master } \\
\text { Doctorate }\end{array}$ & $\begin{array}{l}8.89 \% \\
85.35 \% \\
5.56 \% \\
0.10\end{array}$ & $\begin{array}{l}\text { Most } \\
\text { teachers in } \\
\text { Oman have } \\
\text { an average } \\
\text { educational } \\
\text { qualification } \\
\text { with a portion } \\
\text { of them } \\
\text { having higher } \\
\text { educational } \\
\text { qualifications }\end{array}$ \\
\hline Place of Work & 990 & 11 & $\begin{array}{l}\text { Agency } \\
\text { Government of } \\
\text { Muscat } \\
\text { Government of } \\
\text { Dhofar } \\
\text { Government of } \\
\text { Musandam } \\
\text { Government of Al } \\
\text { Buriami } \\
\text { Dakhiliyah } \\
\text { Governorate } \\
\text { Al Batinah South } \\
\text { Governorate } \\
\text { Al Sharqurah } \\
\text { North Governorate } \\
\text { Al Sharqiyah South } \\
\text { Governorate } \\
\text { A'Dhahira } \\
\text { Governorate }\end{array}$ & $\begin{array}{l}21.62 \% \\
2.93 \% \\
0.91 \% \\
1.11 \% \\
15.15 \% \\
11.41 \% \\
\\
6.64 \\
17.68 \%\end{array}$ & $\begin{array}{l}\text { Teachers are } \\
\text { widespread in } \\
\text { Oman with } \\
\text { most of them } \\
\text { working in } \\
\text { Muscat, the } \\
\text { capital city of } \\
\text { Oman }\end{array}$ \\
\hline
\end{tabular}


INTERNATIONAL JOURNAL OF ACADEMIC RESEARCH IN BUSINESS AND SOCIAL SCIENCES Vol. 10, No. 10, 2020, E-ISSN: 2222-6990 @ 2020 HRMARS

\begin{tabular}{|c|c|c|c|c|c|}
\hline & & & $\begin{array}{l}\text { Al Wusta } \\
\text { Governorate }\end{array}$ & $\begin{array}{l}4.95 \% \\
0.71 \%\end{array}$ & \\
\hline Salary & 996 & 5 & $\begin{array}{l}\text { Rates: } \\
\text { Very Satisfied } \\
\text { Satisfied } \\
\text { Neither satisfied or } \\
\text { dissatisfied } \\
\text { Dissatisfied } \\
\text { Very dissatisfied }\end{array}$ & $\begin{array}{l}17.06 \% \\
41.15 \% \\
15.46 \% \\
\\
16.89 \% \\
8.90 \% \\
\end{array}$ & $\begin{array}{l}\text { Majority of } \\
\text { teachers in } \\
\text { Oman are } \\
\text { satisfied with } \\
\text { their work }\end{array}$ \\
\hline $\begin{array}{l}\text { Opportunitie } \\
\mathrm{s} \quad \text { for } \\
\text { professional } \\
\text { development }\end{array}$ & 996 & 5 & $\begin{array}{l}\text { Rates: } \\
\text { Very satisfied } \\
\text { Satisfied } \\
\text { Neither satisfied or } \\
\text { dissatisfied } \\
\text { Dissatisfied } \\
\text { Very Dissatisfied }\end{array}$ & $\begin{array}{l}3.35 \% \\
15.45 \% \\
19.51 \% \\
\\
37.09 \% \\
24.9 \% \\
\end{array}$ & $\begin{array}{l}\text { Elements and } \\
\text { mechanisms } \\
\text { of } \\
\text { encouraging } \\
\text { teachers in } \\
\text { Oman need to } \\
\text { be enhanced }\end{array}$ \\
\hline $\begin{array}{l}\text { There is a fair } \\
\text { reward } \\
\text { system for } \\
\text { my increased } \\
\text { efforts }\end{array}$ & 996 & 5 & $\begin{array}{l}\text { Very dissatisfied } \\
\text { Very satisfied } \\
\text { Satisfied } \\
\text { Neither satisfied or } \\
\text { dissatisfied } \\
\text { Dissatisfied } \\
\text { Very dissatisfied }\end{array}$ & $\begin{array}{l}2.13 \% \\
7.22 \% \\
13.31 \% \\
35.25 \% \\
42.07 \%\end{array}$ & $\begin{array}{l}\text { The reward } \\
\text { system ought } \\
\text { to be } \\
\text { improved }\end{array}$ \\
\hline $\begin{array}{l}\text { The feedback } \\
\text { from } \\
\text { supervisor's } \\
\text { visits to my } \\
\text { classroom } \\
\text { has been very } \\
\text { useful }\end{array}$ & 995 & & $\begin{array}{l}\text { Very satisfied } \\
\text { Satisfied } \\
\text { Neither satisfied or } \\
\text { dissatisfied } \\
\text { Satisfied } \\
\text { Dissatisfied } \\
\text { Very dissatisfied }\end{array}$ & $\begin{array}{l}10.21 \% \\
28.96 \% \\
25.50 \% \\
\\
29.86 \% \\
22.47 \% \\
12.15 \% \\
\end{array}$ & $\begin{array}{l}\text { Most } \\
\text { teachers are } \\
\text { satisfied with } \\
\text { the feedbacks }\end{array}$ \\
\hline $\begin{array}{l}\text { My division } \\
\text { as a useful } \\
\text { staff program } \\
\text { that has } \\
\text { enabled me } \\
\text { to enhance } \\
\text { my skills as a } \\
\text { teacher }\end{array}$ & 996 & 5 & $\begin{array}{l}\text { Very satisfied } \\
\text { Satisfied } \\
\text { Neither satisfied } \\
\text { nor dissatisfied } \\
\text { Dissatisfied } \\
\text { Very dissatisfied }\end{array}$ & $\begin{array}{l}23.43 \% \\
23.94 \% \\
\\
25.35 \% \\
25.35 \\
20.99\end{array}$ & \\
\hline $\begin{array}{l}\text { The } \\
\text { willingness of } \\
\text { experienced }\end{array}$ & 996 & 5 & Very satisfied & $\begin{array}{l}11.85 \\
42.29 \%\end{array}$ & \\
\hline
\end{tabular}


INTERNATIONAL JOURNAL OF ACADEMIC RESEARCH IN BUSINESS AND SOCIAL SCIENCES Vol. 10, No. 10, 2020, E-ISSN: 2222-6990 @ 2020 HRMARS

\begin{tabular}{|c|c|c|c|c|}
\hline $\begin{array}{l}\text { colleagues to } \\
\text { let you } \\
\text { observe them } \\
\text { teaching }\end{array}$ & & & $\begin{array}{lr}\text { Satisfied } & \text { Neither } \\
\text { satisfied } & \text { nor } \\
\text { dissatisfied } & \\
\text { Dissatisfied } & \text { Very } \\
\text { dissatisfied } & \end{array}$ & $\begin{array}{l}25.33 \% \\
14.61 \% \\
20.99 \%\end{array}$ \\
\hline $\begin{array}{l}\text { Your } \\
\text { relationship } \\
\text { with your } \\
\text { headmaster }\end{array}$ & 996 & 5 & \begin{tabular}{lr}
\multicolumn{2}{l}{ Very satisfied } \\
Satisfied Neither \\
satisfied nor \\
dissatisfied \\
Dissatisfied Very \\
dissatisfied
\end{tabular} & $\begin{array}{l}35.86 \% \\
38.83 \% \\
13.42 \% \\
17.7 \% \\
4.71 \%\end{array}$ \\
\hline $\begin{array}{l}\text { Your } \\
\text { relationship } \\
\text { with your } \\
\text { colleagues }\end{array}$ & 996 & 5 & $\begin{array}{l}\text { Very satisfied } \\
\text { Satisfied Neither } \\
\text { satisfied nor } \\
\text { dissatisfied } \\
\text { Dissatisfied } \\
\text { Very dissatisfied }\end{array}$ & $\begin{array}{l}33.13 \% \\
43.32 \% \\
15.09 \% \\
\\
5.20 \% \\
3.26 \%\end{array}$ \\
\hline $\begin{array}{l}\text { Your } \\
\text { relationship } \\
\text { with your } \\
\text { pupils }\end{array}$ & 996 & 5 & $\begin{array}{l}\text { Very satisfied } \\
\text { Satisfied } \\
\text { Neither satisfied } \\
\text { nor dissatisfied } \\
\text { Dissatisfied Very } \\
\text { dissatisfied }\end{array}$ & $\begin{array}{l}48.97 \% \\
42.49 \% \\
5.56 \% \\
\\
1.95 \% \\
1.03 \% \\
\end{array}$ \\
\hline $\begin{array}{l}\text { Your } \\
\text { personnel } \\
\text { capacity to } \\
\text { manage } \\
\text { pupils' } \\
\text { behaviors }\end{array}$ & 996 & 5 & $\begin{array}{l}\text { Very satisfied } \\
\text { Satisfied } \\
\text { Neither satisfied } \\
\text { nor dissatisfied } \\
\text { Dissatisfied Very } \\
\text { dissatisfied }\end{array}$ & $\begin{array}{l}41.24 \% \\
47.25 \% \\
7.13 \% \\
\\
3.46 \% \\
0.92 \% \\
\end{array}$ \\
\hline $\begin{array}{l}\text { School } \\
\text { support for } \\
\text { managing } \\
\text { pupil's } \\
\text { behaviors }\end{array}$ & 996 & 5 & $\begin{array}{lr}\text { Very } & \text { satisfied } \\
\text { Satisfied } & \text { Neither } \\
\text { satisfied } & \text { nor } \\
\text { dissatisfied } & \\
\text { Dissatisfied } & \text { Very } \\
\text { dissatisfied } & \end{array}$ & $\begin{array}{l}11.77 \% \\
35.11 \% \\
\\
26.10 \% \\
17.71 \% \\
9.31 \% \\
\end{array}$ \\
\hline $\begin{array}{l}\text { Availability of } \\
\text { material } \\
\text { resources for } \\
\text { teaching }\end{array}$ & 996 & 5 & \begin{tabular}{lr}
\multicolumn{2}{l}{ Very satisfied } \\
Satisfied Neither \\
satisfied nor \\
dissatisfied \\
Dissatisfied \\
dissatisfied
\end{tabular} & $\begin{array}{l}8.18 \% \\
29.24 \% \\
21.88 \% \\
\\
26.89 \% \\
13.80 \% \\
\end{array}$ \\
\hline
\end{tabular}


INTERNATIONAL JOURNAL OF ACADEMIC RESEARCH IN BUSINESS AND SOCIAL SCIENCES Vol. 10, No. 10, 2020, E-ISSN: 2222-6990 @ 2020 HRMARS

\section{Discussion}

Education is the most significant and the sole alternative of planting a permanent positive change in the Oman society. Teachers are central towards aiding the Oman society to attain this dream, yet it is almost impossible for them to initiate changes in the practices that may enhance education. Currently, the government of Oman has done a commendable job in numerous areas such as salaries. Indeed, this is not enough when compared to the feeling of the majority of the teachers who feel negative towards the reward system of their job. The government seeks to widen the scope of the horizon for its incoming generation. It is crucial for them to note that knowledge can be imparted, but the learners may end up being not educated if the much-needed transitional changes are not implemented. If the Oman government complies with the findings of this research, then it is going to be well informed about the desired areas they should work to streamline, while seeking to enhance the transitional change of their society into a literate one. Regardless of the few obstacles that the teachers are facing, the government of Oman must be commended for its goodwill with regards to the tremendous steps they have taken to ensure their education system is rationalized.

\section{Conclusion}

The study contributes to the global body of knowledge. All institutions' prime concern is employee motivation to get the higher output. If employees are motivated, it will reflect in their performance. This research provides an overview theoretically and empirically regarding various factors that effects the teachers' motivation and their performance. Whenever there is a shortage of references that are empirical to the study of Oman with regards to teacher's job satisfaction, then researchers are welcome to mirror and reflect these thoughts. As a publication, this paper can be used as a citation and a reference whenever it is relevant to inform the public of the Oman teachers' job satisfaction rates. Being focused on Oman teachers, the paper can serve as resource for comparison and further analysis.

\section{Corresponding Author}

Prof. Dr. Asif Mahbub Karim

Dean , Binary Graduate School

Binary University, Malaysia

Email: drasifmkarim@gmail.com

\section{References}

Adejimi, A., Oyediran, O. S., \& Ogunsanmi, E. B. (2010). Employing qualitatively enriched semi structured questionnaire in evaluating ICT impact on Nigerian 'construction chain integration'. The Built \& Human Environment Review, 3(1), 49-62.

Al Barwani, T. A., Thabit Al-Ani, W., \& Amzat, H. I. (2012). An effective teaching model for public school teachers in the Sultanate of Oman: students' stance. Education, Business and Society: Contemporary Middle Eastern Issues, 5(1), 23-46.

Al Jardani, K. S. S. (2012). A study of educational reform \& teacher training in Oman. International Journal of Applied Linguistics \& English Literature, 1(1), 64-69.

Al-Issa, A. S. (2008). The implications of the teacher training program to the ELT policy implementation in Oman. The Journal of AsiaTEFL, 5(2), 59-92. 
INTERNATIONAL JOURNAL OF ACADEMIC RESEARCH IN BUSINESS AND SOCIAL SCIENCES Vol. 10, No. 10, 2020, E-ISSN: 2222-6990 @ 2020 HRMARS

Al-Mahdy, Y. F., Al-Harthi, A. S., and El-Din, S. N. S.(2016). Perceptions of school principals' servant leadership and their teachers' job satisfaction in Oman. Leadership and Policy in Schools, 15(4), 543-566.

Al-Malki, M. A., and Weir, K. (2014). A comparative analysis between the assessment criteria used to assess graduating teachers at Rustaq College (Oman) and Griffith University (Australia) during the teaching practicum. Australian Journal of Teacher Education, 39(12), 3.

Al-Said, S. K., and Emam, M. M. (2014). Working towards inclusive education in Oman: reflections from teachers of students with learning disabilities in elementary schools. In Proceedings of Braga 2014 Embracing Inclusive Approaches for Children and Youth with Special Education Needs Conference. Braga, Portugal: University of Minho Research Center on Education, 13741.

Al-Senaidi, S., Lin, L., and Poirot, J. (2009). Barriers to adopting technology for teaching and learning in Oman. Computers \& Education, 53(3), 575-590.

Alyahmadi, H., and Al-Kiyumi, A. (2014). The consequences of teacher evaluation on teacher professional development in Oman. International Journal of Education and Research, 2(4), 127-142.

Alyahmadi, H. H. (2012). Teacher performance evaluation in Oman as perceived by evaluators. International Interdisciplinary Journal of Education, 1(1030), 1-8.

Ambusaidi, A., and Al-Shuaili, A. (2009). Science education development in the Sultanate of Oman. In The world of science education, 205-219. Brill Sense.

Amzat, I. H., and Al-Neimi, R. K. R. (2014). Teachers' turnover and their job satisfaction at basic education school in some regions in Oman: structural equation modelling approach. International Journal of Management in Education, 8(1), 78-100.

Bryman, A. (2017). Quantitative and qualitative research: further reflections on their integration. In Mixing methods: Qualitative and quantitative research, 57-78. Routledge.

Cerit, Y. (2010). The effects of servant leadership on teachers' organizational commitment in primary schools in Turkey. International Journal of Leadership in Education, 13(3), 301-317.

Garside, R. (2014). Should we appraise the quality of qualitative research reports for systematic reviews, and if so, how?. Innovation: The European Journal of Social Science Research, 27(1), 67-79.

Ghavifekr, S., and Ibrahim, M. S. (2014). Head of departments' instructional supervisory role and teachers' job performance: teachers' perceptions. Asian Journal of Social Sciences and Management Studies, 1(2), 45-56.

Gonzalez, G., Karoly, L. A., Constant, L., Goldman, C. A., and Salem, H. (2008). Facing human capital challenges of the 21st century: education and labor market initiatives in Lebanon, Oman, Qatar, and the United Arab Emirates (Vol. 786). Rand Corporation.

Issan, S., and Gomaa, N. (2010). Post basic education reforms in Oman: a case study. Literacy Information and Computer Education Journal, 1(1), 19-27.

Issan, S. A., Al-Nabhani, H. Z., Kazem, A. M., and Al-Ani, W. T. (2011). Omani teachers' attitudes towards teaching as a profession. Indian Journal of psychology \& Education, 1(1), 25-40.

Javed, M., Hock, O. Y., Asif, M. K., \& Mohammad, I. H. (2020). Assessing the Impact of Emotional Intelligence on Job Satisfaction Among Private School Teachers of Hyderabad, India. International Journal of Psychosocial Rehabilitation, 24(04), 5035-5045. 
INTERNATIONAL JOURNAL OF ACADEMIC RESEARCH IN BUSINESS AND SOCIAL SCIENCES

Vol. 10, No. 10, 2020, E-ISSN: 2222-6990 @ 2020 HRMARS

Khan, T., and Mishra, G. P. (2013). Promotion as Job Satisfaction, a study on Colleges of Muscat, sultanate of Oman. European Journal of Business and Management, 5(5), 56-62.

Emam, M. (2016). Management of inclusive education in Oman: a framework for Action. Support for Learning, 31(4), 296-312.

Hossain, M. I., Muniandy, K., Nasiruzzaman, M., Karim, A. M. (2018). Factors Influencing Employee High Turnover Rate at Call Centres: A Case Study on AEON Credit Service Malaysia. IOSR Journal of Business and Management (IOSR-JBM) 20.5: 07-15.

Hossain, M. I., Limon, N., Amin, M. T., Asheq, A. S. (2018). Work Life Balance Trends: A Study on Malaysian Generation Y Bankers, IOSR Journal of Business and Management (IOSR-JBM) 20.9: 01-09

Nasser, R. (2019). Educational reform in Oman: system and structural changes. In Education Systems Around the World. IntechOpen.

Sadler, G. R., Lee, H. C., Lim, R. S. H., and Fullerton, J. (2010). Recruitment of hard-to-reach population subgroups via adaptations of the snowball sampling strategy. Nursing \& health sciences, 12(3), 369-374.

Westrick, J. M., and Miske, S. J. (2009). Leadership for innovative Omani schools in the 21st century: transforming principal identity through culturally contextualized training. In Educational Leadership: Global Contexts and International Comparisons (pp. 1-47). Emerald Group Publishing Limited.

Wiseman, A. W. (2009). Educational leadership: global contexts and international comparisons. Bingley, UK, Emerald. 